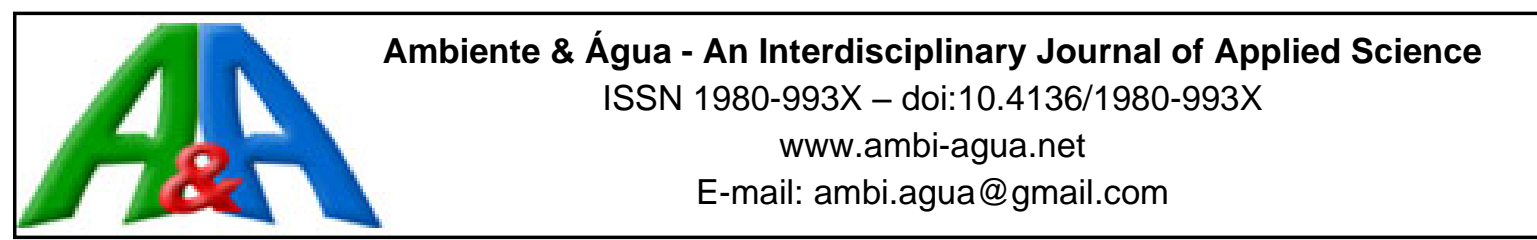

\title{
Comparative analysis between the chlorination and ultraviolet radiation methods for the disinfection of bacteria-contaminated water
}

\author{
ARTICLES doi:10.4136/ambi-agua.2654
}

Received: 02 Oct. 2020; Accepted: 17 Mar. 2021

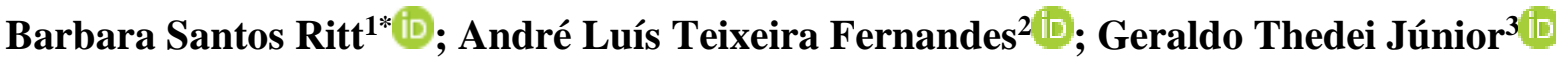

${ }^{\mathbf{1}}$ Mestrado Profissional em Engenharia Química. Universidade de Uberaba (UNIUBE), Avenida Nenê Sabino, $\mathrm{n}^{\circ}$ 1801, CEP: 38055-500, Uberaba, MG, Brazil.

${ }^{2}$ Pró-Reitoria de Pesquisa, Pós Graduação e Extensão. Universidade de Uberaba (UNIUBE), Avenida Nenê Sabino, $n^{\circ}$ 1801, CEP: 38055-505, Uberaba, MG, Brazil. E-mail: andre.fernandes@ uniube.br

${ }^{3}$ Programa de Mestrado Acadêmico em Odontologia. Universidade de Uberaba (UNIUBE), Avenida Nenê Sabino, n 1801, CEP: 38055-505, Uberaba, MG, Brazil. E-mail: geraldo.thedei@ uniube.br

*Corresponding author. E-mail: barbara_ritt@hotmail.com
\end{abstract}

\begin{abstract}
The quality of water for human consumption has been a concern for large organizations and researchers, since the disinfection process, a step of great importance in water treatment plants, has not achieved its proper purpose. There have been frequent reports of the ineffectiveness of bacteria inactivation by the use of chlorine, which is the most used in Brazil, and also due to the formation of by-products such as trihalomethanes and haloacetic acids that are considered toxic to human health. The method of disinfection by ultraviolet radiation (UV) has been widely explored, due to its effectiveness in inactivating a wide variety of pathogens, in addition to the absence of by-product formation. The combined chlorine+UV process as chemical and physical disinfectants, respectively, is complementary and essential when looking for the safety of water for human consumption. The objective of this research was to statistically analyze the performance of disinfectants, chlorine and UV radiation, both separately and together, by inactivating the bacteria Escherichia coli and Pseudomonas aeruginosa and then incubating for 48 hours after having received the treatments. The statistical method showed that chlorine and UV obtained the same significance of $100 \%$ bacteria inactivation, and that within the determined time of 48 hours after the treatments the bacteria did not show reactivation. Thus, the study affirmed the usefulness of applying UV radiation as a complement to systems that use chlorine, with a special focus on residential water systems and supply.
\end{abstract}

Keywords: bacteria inactivation, chlorine, UV light, water treatment.

\section{Análise comparativa entre os métodos de cloração e radiação ultravioleta na desinfecção de água contaminada com bactérias}

\section{RESUMO}

A preocupação com a qualidade da água para consumo humano tem sido alvo de grandes organizações e pesquisadores, visto que o processo de desinfecção, etapa de grande importância nas estações de tratamento de água, não tem alcançado o seu devido propósito. Isso se deve aos frequentes relatos na ineficiência da dose de inativação de bactérias pelo uso do cloro, que é o mais utilizado no Brasil, além da formação de subprodutos como trihalometanos e ácidos 
haloacéticos que são considerados tóxicos a saúde humana. O método de desinfecção por radiação ultravioleta (UV) tem sido amplamente explorado, devido à sua eficiência em inativar uma grande variedade de patógenos, além da ausência da formação de subprodutos. O processo combinado cloro+UV como agentes desinfetantes químicos e físicos, respectivamente, tornaos complementares e essenciais quando se busca a segurança da água para consumo humano. O objetivo desta pesquisa foi analisar estatisticamente o desempenho dos agentes desinfetantes, cloro e radiação UV, separadamente e em conjunto, por meio da inativação das bactérias, Escherichia coli e Pseudomonas aeruginosa, após 48 horas incubadas, após terem recebido os tratamentos. Concluiu-se que o cloro e a UV obtiveram a mesma significância de $100 \%$ de inativação das bactérias e que, dentro do tempo determinado de 48 horas após os tratamentos, as bactérias não mostraram reativação. Desta forma, o estudo realizado permitiu a consolidação da boa perspectiva de aplicação da radiação UV como complemento aos sistemas baseados no uso do cloro, com especial enfoque para sistemas e abastecimento de água residenciais.

Palavras-chave: cloro, inativação de bactérias, luz ultravioleta, tratamento de água.

\section{INTRODUCTION}

Water disinfection is a process of extreme importance to humanity. To obtain efficient disinfection it is necessary to reduce the microorganisms to an acceptable level, within the regulatory parameters, so that the consumption of treated water is safe for health, avoiding any type of disease or damage. Some of the main difficulties in water disinfection are the selection of a process that reduces microbiological load to established standards, has a minimum formation of by-products, and that is the most economically advantageous, while considering biosecurity (Sakai, 2012).

According to Souza (2006), chlorine is the main disinfectant used in Brazil to disinfect the water supply. This is due to its ample germicidal power, active residual formation that allows for biosecurity from the Treatment Station to the final consumer and a low operating cost. However, in many cases studied, research links outbreaks of emerging diseases with chlorination insufficiency. This may be related to the existence of chlorine-resistant microorganisms, which under normal conditions were not inactivated in the disinfection systems, as is the case of the bacterium Pseudomonas aeruginosa (Aguiar, 2000).

In addition, chlorine produces toxic carcinogenic by-products such as haloacetic acids (HAA), and trihalomethanes (THMs) when in contact with organic compounds present in raw water (Pianowski and Janissek, 2003). With this, the potential for the formation of halogenated by-products, when natural waters are disinfected with chlorine, contributed to important changes in the water supply and public health sectors around the world (Souza and Daniel, 2005). In Brazil, however, there is some resistance to the application of new disinfection technologies on large scales.

Ultraviolet light - C (UVC) is an intervention technology approved by the FDA (Food and Drug Administration) that can be used to inactivate pathogenic bacteria in liquid foods, water, food contact surfaces and food surfaces (Sommers et al., 2010). The biological effects of UV radiation derive from the excitation and not the ionization of molecules (Karel and Lund, 2003). Energy and a germicidal medium do not create residual radioactivity like ionizing radiation (gamma radiation). At the germicidal wavelength, UV radiation is sufficient to cause physical displacement of electrons and break bonds in the deoxyribonucleic acid (DNA) of the microorganisms. This process alters their metabolism and reproduction; that is, there is injury to the cell's reproduction systems that leads to death (Guerrero-Beltrán and Barbosa-Cánovas, 2004).

Rev. Ambient. Água vol. 16 n. 2, e2654 - Taubaté 2021 
According to Daniel (2001), combined disinfection, commonly called interactive disinfection, involves taking advantage of the synergistic effect of two or more disinfectants. When using only one disinfectant there may be flaws in its performance against protozoans and resistant organisms. Regarding this, a lot of research has studied combinations of disinfectants that can complement each other. Thus, the objective of this research was to statistically analyze the results obtained from inactivation disinfection processes by means of chlorination using sodium hypochlorite $(\mathrm{NaClO})$, an ultraviolet radiation reactor (UV), and the combination of the two methods in raw water contaminated by Escherichia coli and Pseudomonas aeruginosa. Both are indicators of water quality in accordance with Brazilian Legislation Ordinance No. 2.914/2011 (Brasil, 2011), which provides procedures for the control and surveillance of water quality for human consumption and its standard of potability.

\section{MATERIALS AND METHODS}

The experiments were conducted at the Cellular and Molecular Biology Laboratory at the University of Uberaba (UNIUBE). The experiments were undertaken to determine the ideal range of bacteria $\left(\mathrm{CFU} \mathrm{ml}{ }^{-1}\right)$ for raw water contamination, the process of chlorine disinfection, ultraviolet radiation and the combined process of both.

To evaluate these different processes, experiments were divided into Stage 1 and Stage 2 in view of the research objective. The experiments related to Stage 1 consisted of repetitions to find the best dilution that would allow for the contamination of 20 litres of raw water in order to test the chlorine disinfectant effectiveness and the UV reactor. The experiments referring to Stage 2 were conducted in two distinct phases due to the need to avoid cross-contamination of the worked bacteria so that the results of the analyses were not compromised. Phase 1 regarded the tests based on $E$. coli inactivation, and Phase 2 regarded the tests based on P.aeruginosa inactivation.

For all experiments, both in Stage 1 and in Stage 2, raw water was used. We opted to work with the raw water captured in one of the artesian wells at the University of Uberaba (UNIUBE) due to its quality in terms of physical-chemical parameters and the intention to keep the disinfection process close to the real one, both for chlorine and the UV reactor that is installed in homes. The use of distilled water and synthetic water for the experiments was therefore discarded.

In Stage 1, initially, the two strains, Pseudomonas aeruginosa NEW 0027 (1242) NEWPROV - Similar to ATCC 9027 and Escherichia coli ATCC 25922, kept lyophilized, were incubated in BHI broth (Brain Heart Infusion) for 24-h at 37degrees C. They were later stored in cryogenics at -70 degrees $\mathrm{C}$ in cryotubes containing $\mathrm{BHI}$ broth medium and $50 \%$ glycerin. For use in the research, the cryo-preserved strains were reactivated in $10 \mathrm{ml}$ of BHI broth at 37 degrees $\mathrm{C}$ for $24-\mathrm{h}$.

After reactivation, aliquots of the reactivated ATCC strains were subjected to optical density measurements, $600 \mathrm{~nm}$ (spectrophotometer PG Instruments model T60U) and diluted in sterile $0.9 \%$ saline until absorbances equal to 0.2 .

To determine ideal bacterial dilution, $100 \mu \mathrm{l}$ of each culture at 0.2 absorbance,was subjected to serial decimal dilution up to $10^{8}$ using a sterile BHI medium. After each $100 \mu \mathrm{l}$ was spread over solidBHI medium in duplicate, using the Drigalsky loop and with incubation at 37degrees $\mathrm{C}$ for 24-h, the number of colony-forming units were determined.

With the results obtained in the standardization, it was decided to work with the $10^{5}$ dilution, which had an average of 150 colonies $100 \mu \mathrm{l}^{-1}$, since the recommendation is to work in the range of 30 to 300 colonies, according to the Microbiological Water Analysis Methods Manual (Silva et al., 2005), corresponding to an ideal range for contamination. To determine how many $\mathrm{ml}$ would be required to contaminate 20 litres or $20.000 \mathrm{ml}$ of water, it was necessary to find the CFU per $1 \mathrm{ml}$ of the $10^{5}$. The bacterial concentration was adjusted to 
$1.5 \cdot 10^{8} \mathrm{CFU} \mathrm{ml}{ }^{-1}$. Dilution was determined using Equation 1 below:

$\frac{C F U}{m l}=\frac{N o \text { colonies } \cdot 10}{\text { dilution }}$

To quantify the dosage of chlorine to be used for the disinfection of contaminated water, the recommendations of the information released by the Ministry of Health through the Department of Health Surveillance of 2006 (Brasil, 2006) were followed. For $20 \mathrm{~L}$ of water treated for human consumption, it is necessary to include $5 \mathrm{ml}$ of sodium hypochlorite $(\mathrm{NaClO})$ at a concentration of 2.0 to $2.5 \%$ for 15 minutes.

For the chlorination treatment $5 \mathrm{ml}$ of hypochlorite was used in $20 \mathrm{~L}$ of water, according to Brasil (Funasa, 2014), in order to obtain the concentration of $6.25 \mathrm{ppm}$ (parts per million)

All the experiments were repeated 3 times and the data presented came from the average of at least 3 independent experiments.

With data on the microbiological load required to contaminate 20 litres of water, in addition to the chlorine dosage, the bacterial concentration was determined after 5 different tests (Step 2).

1) Raw water;

2) Water contaminated with the bacteria;

3) Contaminated water treated with UV radiation;

4) Contaminated water treated with chlorine;

5) Contaminated water treated with chlorine and UV radiation;

The trials lasted six weeks, so that the first three were conducted on the E.coli bacteria and the following were with $P$. aeruginosa, to avoid cross-contamination.

Initially, $20 \mathrm{~L}$ of water were contaminated with the number of bacteria needed (as described above) to obtain about $150 \mathrm{CFU} 100 \mu \mathrm{l}^{-1}$. Then, the contaminated water passed through the UV reactor (Test 3) or was treated with hypochlorite (Test 4) or both treatments (Test 5) and a sample of approximately $50 \mathrm{ml}$ was collected in a previously sterilized flask to determine the number of CFU ml${ }^{-1}$. As a control, raw water (Test 1) and water contaminated with bacteria (Test 2) were used.

The samples were subjected to serial dilution $(100 \mu \mathrm{l}+900 \mu \mathrm{l}$ of sterile BHI culture medium) and plated in solid BHI medium as described above.

The ultraviolet radiation reactor used was the VIQUA ABSOLUTE $\mathrm{H}_{2} \mathrm{O}^{\circledR}(\mathrm{UV}-1 / 2)$ provided by the company ARAUNAH TECH in a partnership between the company and the University of Uberaba in order to contribute to the development of the research. VIQUA UV$1 / 2{ }^{\circledR}$ is a residential system consisting of four main components. These are the reactor chamber, the UV lamp ( $9 \mathrm{~W}$, maximum rated flow at dose, $\left.30 \mathrm{~mJ} \mathrm{~cm}^{2-1}\right)$, the quartz glove, and the control unit.

To test the effectiveness of chlorine, $20 \mathrm{~L}$ of water were contaminated with bacterial suspension of E.coli and P.aeruginosa, (as described above) to obtain the concentration of 150 $\mathrm{CFU} \mathrm{ml} \mathrm{m}^{-1}$. The contaminated water was then guided by gravity (Figure 1) to the reactor, at a flow rate of $90 \mathrm{~mL} \mathrm{~s}^{-1}$. Under these conditions, the dose of radiation emitted is $30 \mathrm{~mJ} \mathrm{~cm}{ }^{2-1}$.

To test the effectiveness of the UV + chlorine association, the water was contaminated with the bacteria, treated with chlorine and then passed through the reactor, as described above.

After each treatment, a sample of the treated water was collected in a sterile flask for plating in BHI medium and to determine the number of $\mathrm{CFU} \mathrm{ml}{ }^{-1}$ (as described above). After the 24 -h incubation at 37 degrees $\mathrm{C}$, the number of colonies was determined by manual colony 
counting. The number of CFU ml ${ }^{-1}$ was determined taking into account the sample dilution before plating and the inoculated volume.

The structure assembled for the experiment consisted of a 2-meter-high shelf divided into three levels upon which the 20-gallon containers of contaminated water (A), the UV apparatus (B), the non-toxic hoses (C), and the container for disposal (D) were placed. As seen in Figure 1, water enters the reactor at the bottom of UV apparatus (E) and the treated water exits at the top of the reactor $(\mathrm{F})$.

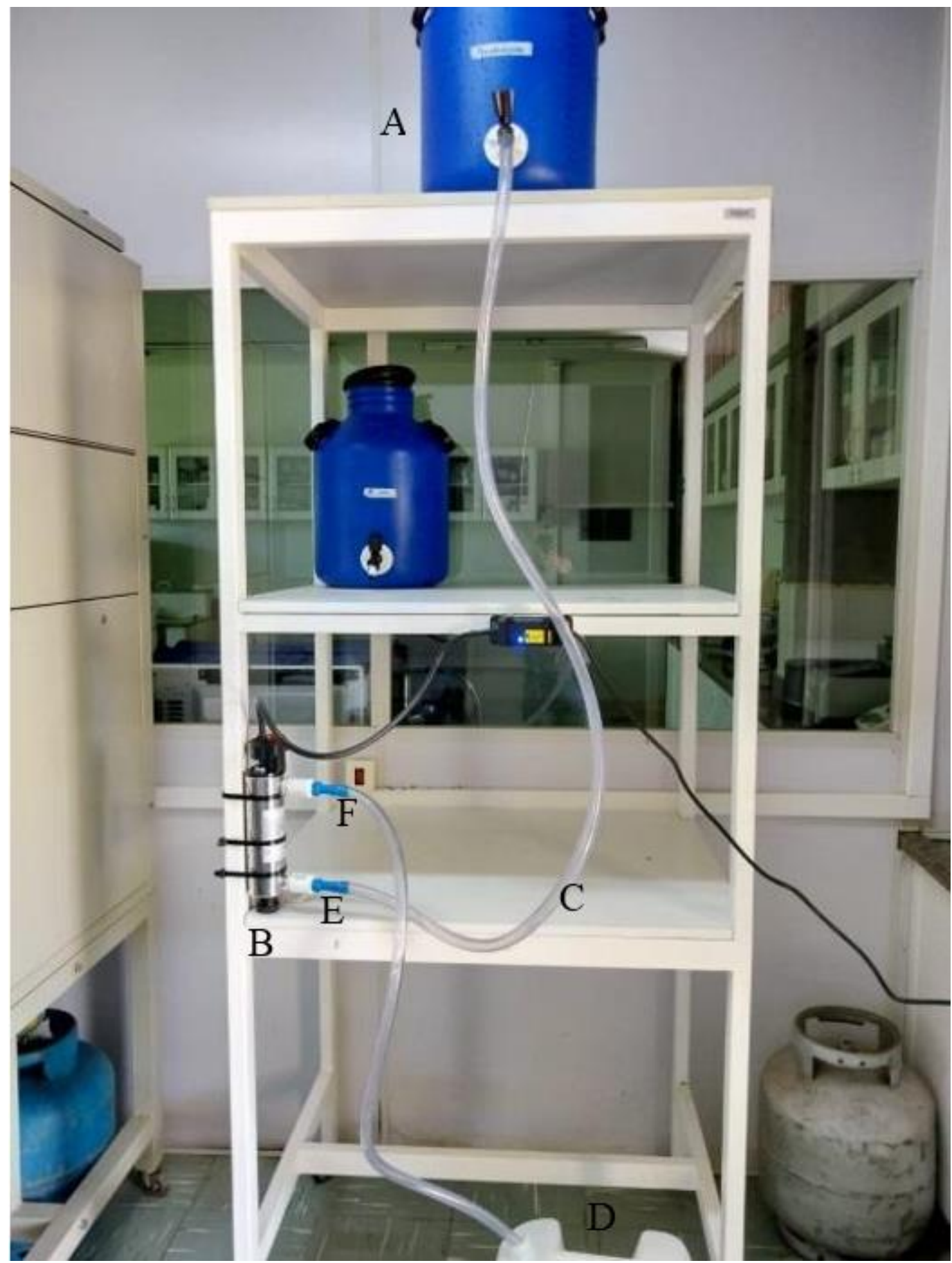

Figure 1. Structure of the disinfection system.

Source: Personal archive (2019).

For data purposes, the GraphPad Prism 7 program was used, to initially verify which statistical method would be the most suitable. From the D'Agostino \& Pearson and Shapiro- 
Wilk normality tests, non-normality was found, thus discarding the use of Standard Deviation as a statistical method. With that, it is recommended to use non-parametric ANOVA of the Kruskal-Wallis followed by Dunn's multiple comparison test. The data were expressed as the median, minimum and maximum values Skewness and Kurtosis and later Dunn's multiple comparison test. For all statistical analysis, the significance level was 5\% ( $\mathrm{p}<0.05)$.

After the chlorine, UV or chlorine + UV treatments, a sample of the treated water was stored in the growth chamber at 37 degrees $\mathrm{C}$. This bacterial suspension was gently agitated and plated in sterile BHI medium. From each test, 4 plates were sown for bacterial count after treatment. These plates were then stored in the growth chamber for 48 hours to check for any recovery of bacterial viability.

\section{RESULTS AND DISCUSSION}

The chlorine, UV and chlorine + UV treatments significantly reduced the bacterial load of water contaminated with E.coli (Table 1) and P.aeruginosa (Table 2). Thus, it was inferred that there was no resumption of cell viability after treatment. Such an observation reinforces the effectiveness of the treatments, suggesting that the inactivation observed after the treatment is definitive, with no possibility of the resumption of metabolism or cell viability. For example, the loss of function in the intracellular and DNA repair systems in the period of time the study was conducted. The Kruskal-Wallis test determined the median, minimum and maximum values, according to Tables 1 and 2 below.

Table 1. Effect of different treatments on the bacterial count of water contaminated with E.coli.

\begin{tabular}{cccccc}
\hline Parameters & Raw $^{*}$ & Contaminated* & UV $^{*}$ & Chlorine* & Chlorine+UV* \\
\hline Median & $1 \cdot 10^{3}$ & $1.53 \cdot 10^{5}$ & 0 & 0 & 0 \\
Minimum & 0 & $1.01 \cdot 10^{5}$ & 0 & 0 & 0 \\
Maximum & $1.7 \cdot 10^{4}$ & $1.92 \cdot 10^{5}$ & 0 & $1 \cdot 10^{3}$ & 0 \\
Skewness & 2.4 & $-0,15$ & - & 0.39 & - \\
Kurtosis & 5.1 & -1.4 & - & -2.3 & - \\
\hline
\end{tabular}

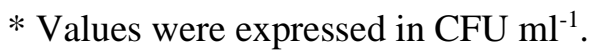

Table 2. Effect of different treatments on the bacterial count of water contaminated with $P$. aeruginosa.

\begin{tabular}{cccccc}
\hline Parameters & Raw $^{*}$ & Contaminated* & UV* $^{*}$ & Chlorine* & Chlorine+UV* \\
\hline Median & 0 & $1.39 \cdot 10^{5}$ & 0 & 0 & 0 \\
Minimum & 0 & $1.06 \cdot 10^{5}$ & 0 & 0 & 0 \\
Maximum & $1 \cdot 10^{3}$ & $1.65 \cdot 10^{5}$ & 0 & 0 & 0 \\
Skewness & 1.3 & -0.059 & - & - & - \\
Kurtosis & -0.33 & -1.1 & - & - & - \\
\hline
\end{tabular}

* Values were expressed in $\mathrm{CFU} \mathrm{m} \mathrm{m}^{-1}$.

Tables 1 and 2 show that for the UV, chlorine and combined processes, the median values were equal to 0 . This shows that $100 \%$ effectiveness was obtained in the inactivation of bacteria.

Except the chlorine treatment in Table 1, which, when the maximum was analyzed $\left(1 \cdot 10^{3}\right.$ $\mathrm{CFU} \mathrm{ml^{-1 }}$ ), showed that the Skewness and Kurtosis values were non-existent, as they did not have values to be analyzed.

Still using the Kruskal-Wallis statistical method, but now following Dunn's multiple comparison test, all the tests versus all of the E.coli and P.aeruginosa bacteria tests were 
analyzed to better assess all existing data. The results for the two bacteria were the same and are represented in Table 3 below.

Table 3. Result values from Dunn's multiple comparison test for E.coli and P.aeruginosa.

\begin{tabular}{ccc}
\hline All x all & Significant & Summary \\
\hline Raw vs. Contaminated & Yes & $* *$ \\
Raw vs. UV & No & ns \\
Raw vs. Chlorine & No & ns \\
Raw vs. UV+ Chlorine & No & ns \\
Contaminated vs. UV & Yes & $* *$ \\
Contaminated vs. Chlorine & Yes & $* *$ \\
Contaminated vs. UV+Chlorine & Yes & $* *$ \\
UV vs. Chlorine & No & ns \\
UV vs. UV+Chlorine & No & ns \\
Chlorine vs. UV+Chlorine & No & ns \\
\hline
\end{tabular}

ns: non- significant.

$* *(\mathrm{p}<0.05)$.

Through Table 3, it was possible to verify that it was significant only when the tests were compared with the contaminated water, in which there was a bacterial concentration value that was reduced to 0 by the disinfection treatments.

In his research, Lobo (2008) used a UV radiation reactor to evaluate the inactivation of Escherichia coli and Saccharomyces cerevisiae. The greatest inactivation, $99.96 \%$, was obtained with a sample containing $3.65 \cdot 10^{3} \mathrm{CFU} \mathrm{ml}^{-1}$ of viable E. coli cells irradiated for $60 \mathrm{~s}$ by UV at an estimated radiation dose of $9.2 \mathrm{mWs} \mathrm{cm}{ }^{2-1}$ or $9.2 \mathrm{~mJ} \mathrm{~cm}^{2-1}$. At approximately 20 hours after treatment the irradiated $E$. coli cells showed reactivation. In the present experiment, using a reactor with a radiation dose of $30 \mathrm{~mJ} \mathrm{~cm}{ }^{2-1}$, containing on average in the sample $1.53 \cdot 10^{5} \mathrm{CFU} \mathrm{ml}^{-1}$ of E. coli, $100 \%$ inactivation was obtained and after 48 hours of storage there was no reactivation, contrary to what Lobo (2008) had as a result in his study. This observation is of great relevance and validates the effectiveness of the reactor used due the possibility of enzymatic photoreactivation.

Wisbeck et al. (2011), evaluated the treatment of rainwater by ultraviolet radiation, analyzing total coliforms, tolerant coliforms and heterotrophic bacteria before, after and then after being translated and stored for 24, 48 and 72 hours. With a $30 \mathrm{~W}$ lamp and a flow rate of $0.04 \mathrm{~s}^{-1}$, it achieved $100 \%$ effectiveness in the inactivation of total and fecal coliforms for up to 72 hours, unlike the heterotrophic bacteria that identified in the 3 storage times after treatment. With a flow rate of $0.091 \mathrm{~s}^{-1}$ and $9 \mathrm{~W}$ lamp, we achieved $100 \%$ inactivation after UV treatment and after 48 hours of E.coli and P.aeruginosa storage.

Complementing the importance of studying the combined chlorine $+\mathrm{UV}$ process, according to Daniel (2001), certain disinfectants, despite being effective, do not leave a longlasting residual necessary to stabilize the microbial population in the water distribution system. Thus, the interactive disinfection that consists of the synergistic effect of two or more chemical and physical disinfections is necessary, because if one fails, the other guarantees safe drinking water.

In spite of several studies that demonstrate the efficiency of UV radiation as a water disinfectant, as well as its feasibility and benefits, Ordinance No. 2.914/2011, which provides the control and surveillance procedures of water quality for human consumption and it's potability standard, in Chapter IV, Article 24, states that all water for human consumption, supplied collectively, must undergo a disinfection or chlorination process. And in Article 35 it 
is stated that in the case of the use of ozone or ultraviolet radiation as a disinfectant, chlorine or chlorine dioxide must be added in order to maintain a minimum residual in the distribution system (reservoir and network).

\section{CONCLUSIONS}

The disinfection processes were highly effective, achieving $100 \%$ inactivation of both tested bacteria. The bacterial inactivation was definitive, as there was no bacterial growth even after 48 hours of incubation of the bacteria in such a condition after the treatments. Due to the limited literature that addresses UV + chlorine as a water treatment for human consumption, there is a need for further studies to expand on the benefits of using the residential UV reactor for disinfecting water by testing with other pathogens and parameters.

\section{ACKNOWLEDGEMENTS}

The authors would like to thank the company ARAUNAH TECH SOLUÇÕES TECNOLÓGICAS for providing the ultraviolet disinfection reactor, VIQUA ABSOLUTE $\mathrm{H} 2 \mathrm{O}{ }^{\circledR}$, the University of Uberaba (Program of Master in Chemical Engineering) and Fundação de Amparo e Pesquisa de Minas Gerais FAPEMIG for the support given during the development of this research.

\section{REFERENCES}

AGUIAR, A. M. de S. Avaliação do emprego da radiação ultravioleta na desinfecção de águas com cor e turbidez moderadas. 2000. 107p. Dissertação (Mestrado) Universidade Federal de Minas Gerais, Belo Horizonte, 2000.

BRASIL. Ministério da Saúde. Portaria n. 2.914, de 12 de dezembro de 2011. Dispõe sobre os procedimentos de controle e de vigilância da qualidade da água para consumo humano e seu padrão de potabilidade. Diário Oficial [da] União: seção 1, Brasília, DF, p. 39, 14 de dez. de 2011.

BRASIL. Ministério da Saúde. Secretaria de Vigilância em Saúde. Vigilância e controle da qualidade da água para consumo humano. Brasília, DF, 2006. 212 p.

DANIEL, L. A. Processos de desinfecção e desinfetantes alternativos na produção de água potável. PROSAB (Rede Cooperativa de Pesquisas), São Carlos: Rima Artes e Textos, 2001. 139p.

FUNASA (Brasil). Manual de cloração de água em pequenas comunidades: utilizando o clorador simplificado desenvolvido pela FUNASA. Brasília, DF, 2014. 36 p.

GUERRERO-BELTRÁN, J. A.; BARBOSA-CÁNOVAS, G. V. Advantages and limitations on processing foods by UV light. Food Science and Technology International, v. 10, n. 3, p. 137-147, 2004. https://doi.org/10.1177\%2F1082013204044359

KAREL, M.; LUND, D. B. Physical principles of food preservation. New York: Marcel Dekker, 2003.

LOBO, M. G. Avaliação da desinfecção de água por reator utilizando radiação ultravioleta. 2008. 88p. Trabalho (Dissertação) - Universidade da região de Joinville, Joinville, 2008. 
PIANOWSKI, E. H.; JANISSEK, P. R. Desinfecção de efluentes sanitários com uso de cloro: avaliação da formação de trihalometanos. Curitiba: SANARE, 2003. 12p.

SAKAI, S. Desinfecção de água: os principais sistemas disponíveis no mercado. 10. ed. São Paulo: Revista TAE, 2012.

SILVA, N.; JUNQUEIRA, V. C. A.; SILVEIRA, N. F. DE A.; CANTÚSIO NETO, R. Manual de métodos de análise microbiológica de alimentos e água. São Paulo: Livraria Varela, 2005. 164p.

SOMMERS, C. H.; SITES, J. E.; MUSGROVE, M. Ultraviolet light (254 nm) inactivation of foodborne pathogens on foods and stainless steel surfaces. Journal of Food Safety, v. 30, n. 2, p. 470-479, 2010. https://doi.org/10.1111/j.1745-4565.2010.00220.x

SOUZA, J. B. de. Avaliação de métodos para desinfecção de água, empregando cloro, ácido peracético, ozônio e o processo de desinfecção combinado ozônio/cloro. 2006. 190p. Tese (Doutorado) - Escola de Engenharia de São Carlos, Universidade de São Paulo, São Carlos, 2006.

SOUZA, J. B. de; DANIEL, L. A. Comparação entre hipoclorito de sódio e ácido peracético na inativação de E.coli, colifagos e $C$. perfringens em água com elevada concentração de matéria orgânica. Engenharia Sanitária e Ambiental, v. 10, n. 2, 2005. https://doi.org/10.1590/S1413-41522005000200004

WISBECK, E; SANDRI, E. K.; SOARES, A. L. M.; MEDEIROS, S. H. W. Desinfecção de água de chuva por radiação ultravioleta. Engenharia Sanitária e Ambiental, v. 16, n. 4 , p. 337-342, 2011. https://doi.org/10.1590/S1413-41522011000400004 